\title{
PREVENTION OF HYPOVITAMINOSIS AND HYPOMICROELEMENTOSIS IN THE UNIVERSITY STUDENTS
}

\author{
Yeltsova L.B., Omelchuk S.T., Aleksiichuk V.D., Petrosian A.A.
}

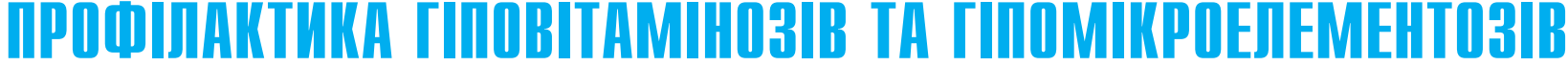 У СТУДЕНТСЬКОї МОЛОДІ}

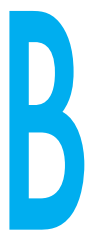

ЄЛЬЦОВА Л.Б., ОМЕЛЬЧУК С.Т., АЛЕКСІЙЧУК В.Д., ПЕТРОСЯН А.А.

Національний медичний університет

ім. О.О. Богомольця, м. Київ

УДК 577.16+577.118]:616008.64-057.875-084

https://doi.org/10.32402/ dovkil2018.04.053

Ключові слова: частота споживання, опитувальна карта, продукти харчування рослинного походження, раціон харчування, аліментарні захворювання, корекція, студентська молодь. ідповідно до оновлених в Україні Норм фізіологічних потреб населення в основних харчових речовинах та енергії і рекомендацій щодо здорового харчування дорослих, тарілка здорового харчування на $1 / 2$ складається 3 овочів, бобових, фруктів, ягід та на 1/6 з хліба, хлібних, макаронних виробів, круп, цільнозернових продуктів, горіхів та насіння $[2,3]$

Користь від споживання натуральних рослинних продуктів доведена у багаторічних дослідженнях $з$ залученням мільйонів людей у різних країнах. Продукти харчування рослинного походження (овочі, фрукти, ягоди) сприяють зниженню рівня загальної захворюваності, покращують якість життя та подовжують тривалість життя, підвищують рівень працездатності [3].

Продукти харчування рослинного походження вважаються основою здорового харчування. Вони є основним джерелом над- ходження до організму вуглеводів з низьким глікемічним індексом, харчових волокон, вітамінів, вітаміноподібних речовин та мінералів, біофлавоноїдів [4, 8]. Фахівці рекомендують населенню споживати до 4-5 видів овочів та 2-3 види фруктів на добу 300 г овочів на 4-5 порцій, 75 г бобів, 300 г фруктів та ягід на 2 порції [3-6]. Встановлено, що кожна додаткова порція (80 г) овочів та фруктів зумовлюе зменшення смертності через серцево-судинні захворювання приблизно на 4\% [4, 7]. Збільшення їх присутності асоційоване зі зменшенням ризику онкологічних захворювань [3, 4]. Розуміння цінності наявності у раціоні такої групи продуктів харчування зробить вибір у харчуванні легшим та здоровим і суттєво покращить здоров'я.

Визначення частоти споживання продуктів харчування рослинного походження у раціоні дає можливість вчасно оцінюва-
ПРОФИЛАКТИКА ГИПОВИТАМИНОЗОВ И ГИПОМИКРОЭЛЕМЕНТОЗОВ У СТУДЕНЧЕСКОЙ МОЛОДЕЖИ

Ельцова Л.Б., Омельчук С.Т. Алексийчук В.Д., Петросян А.А. Национальный медицинский университет им. А.А. Богомольца, г. Киев, Украина

Цель: оценка частоты употребления продуктов питания растительного происхождения в рационе студенческой молодежи с целью профилактики гиповитаминозных и гипомикроэлементозных состояний.

Материалы и методы: с помощью картыопросника [1] была собрана информация и проведена оценка результатов исследования рационов студентов-медиков 2, 4, 6 курсов медицинских факультетов НМУ имени

А.А. Богомольца. Объем выборки - 858 респондентов. Возраст - от 18 до 25 лет, из них 570 респондентов женского пола и 288 мужского. Результаты. Представлены результаты оценки частоты употребления продуктов питания растительного происхождения в рационе студентовмедиков. Частота употребления данных продуктов оценивалась по такой шкале: употребление один раз в день или чаще, почти каждый день, один раз в неделю, несколько раз в неделю, один или несколько раз в месяц, редко или никогда. Оценивалась частота употребления таких групп продуктов питания растительного происхождения: овощей, включая традиционные для украинцев свеклу, морковь, капусту и зелень. Отдельно оценивали употребление картофеля, учитывая национальные пищевые предпочтения, а также фруктов и ягод, хлеба и хлебобулочных изделий, сладостей (сахар, варенье, мед), круп и макаронных изделий. Вывод. Установлено, что лишь треть респондентов женского пола использует в своем рационе овощи ежедневно и 15-25\% респондентов мужского пола. От 17\% респондентов женского пола (2 курс) до 25\% (6 курс), а также треть респондентов мужского пола, независимо от курса обучения, ежедневно используют в рационе картофель. До 40\% респондентов мужского пола и до $31 \%$ респондентов женского пола ежедневно употребляют фрукты. Хлеб и хлебобулочные изделия потребляют ежедневно до 40\% респондентов мужского пола и до 30\% женского. Ежедневно или почти каждый день потребляют крупы и макаронные изделия до 30\% респондентов мужского пола и 15-19\% женского. Употребляют ежедневно сладости (сахар, варенье, мед) треть респондентов мужского пола и лишь 10-12\% респондентов женского пола. В общем 70\% студенческих рационов по их наполнению продуктами растительного происхождения не отвечают национальным рекомендациям по питанию.

Ключевые слова: частота употребления, карта-опросник, продукты питания растительного происхождения, рацион питания, алиментарные заболевания, коррекция, студенческая молодежь.

() Єльцова Л.Б., Омельчук С.Т., Алексійчук В.Д., Петросян А.А. СТАТТЯ, 2018. 
ти та попереджати виникнення нутрієнтних дефіцитів (гіповітамінозів, гіпомікроелементозів) та аліментарнозалежних захворювань.

Мета: оцінка частоти споживання продуктів харчування рослинного походження у раціоні студентської молоді 3 метою профілактики гіповітамінозних та гіпомікроелементозних станів.

Матеріали та методи дослідження. Поперечне (кроссекційне) засліплене дослідження. Анкетування проводилось анонімно за попередньою згодою респондентів з кінця грудня 2016 до кінця лютого 2017 року. У цей період (осіннє-зимовий, зимово-весняний) найбільш виражені прояви дефіцитного харчування. Анкетування проводили заздалегідь підготовлені інтерв'юери, які пройшли спеціальну підготовку та перевірку техніки інтерв'ювання.

Критерієм включення були студенти-медики 2, 4, 6 курсів. Критерієм виключення - студенти, які тимчасово або тривалий час мали лікувально-профілактичне, дієтичне чи лікувальне харчування, хронічні захворювання у стадії суб- та декомпенсації, віддавали перевагу нетрадиційним видам харчування (вегетаріанці, сироїди), вагітні (2 та 3 триместри).

У дослідженні використовувалися такі методи: аналітичний, анкетно-опитувальний, стати- стичний (програма Medstatistika). Використовувалася опитувальна карта, розроблена фахівцями кафедри гігієни та екології № 4 НМУ імені О.О. Богомольця, яка пройшла експертну оцінку провідних науковців у галузі гігієни харчування, дієтології [1]. Було проанкетовано 858 респондентів, серед них студенти медики 2, 4, 6 курсів медичних факультетів № 3, № 4 та факультету підготовки лікарів для Збройних Сил України. Формування вибірки випадкове. Вік респондентів - від 18 до 25 років, з них 570 респондентів жіночої статі та 288 чоловічої. Респондентів 2 курсу жіночої статі 213 , чоловічої - 126, респондентів 4 курсу жіночої статі - 192, чоловічої - 89, респондентів 6 курсу жіночої статі - 165, чоловічої - 73.

Результати та обговорення. За допомогою опитувальної карти було зібрано інформацію та проведено оцінку результатів дослідження раціонів студентівмедиків, а саме: частоти споживання продуктів харчування рослинного походження, яку оцінювали відносно споживання протягом дня, тижня, місяця: споживання один раз на день або майже щодня, один раз чи декілька разів на тиждень, один або декілька разів на місяць, рідко або ніколи. Проводили оцінку частоти споживання таких груп продуктів рослинного походження: овочів, у т.ч. традиційних для українців буряка, моркви, капусти, та зелені. Окремо оцінювали споживання картоплі, враховуючи національні харчові вподобання. Оцінювали частоту споживання фруктів та ягід, хліба та хлібобулочних виробів, солодощів (цукру, варення, меду), круп та макаронних виробів.

При оцінюванні частоти споживання овочів виявлено, що до свого раціону їх щоденно або майже щодня включають 14,3\% та $27,0 \%$ відповідно чоловічої статі і $26,8 \%$ та $38,5 \%$ жіночої (рис. 1).

Також виявлено, що до свого раціону овочі включають 1 раз на тиждень або декілька разів на тиждень $16,65 \%$ та 26,2\% чоловічої статі і $13,6 \%$ та 10,3\% жіночої; 1 чи декілька разів на місяць або рідко чи ніколи - $11,1 \%$ та $4,75 \%$ чоловічої статі і $6,1 \%$ та $4,7 \%$ жіночої статі; щоденно або майже щодня включають 23,7\% та $14,7 \%$ відповідно респондентів 4 курсу чоловічої статі $31,25 \%$ та 30,7\% жіночої; 1 раз на тиждень або декілька разів на тиждень - 23,7\% та 20,25\% чоловічої статі і $18,25 \%$ та $13,0 \%$ жіночої; 1 чи декілька разів на місяць або рідко чи ніколи $12,35 \%$ та 5,6\% чоловічої статі і $5,2 \%$ та 1,6\% жіночої; щоденно або майже щодня включають $17,8 \%$ та $37,0 \%$ відповідно респондентів 6 курсу чоловічої статі і

\section{Частота споживання овочів студентами-медиками}

Рисунок 1
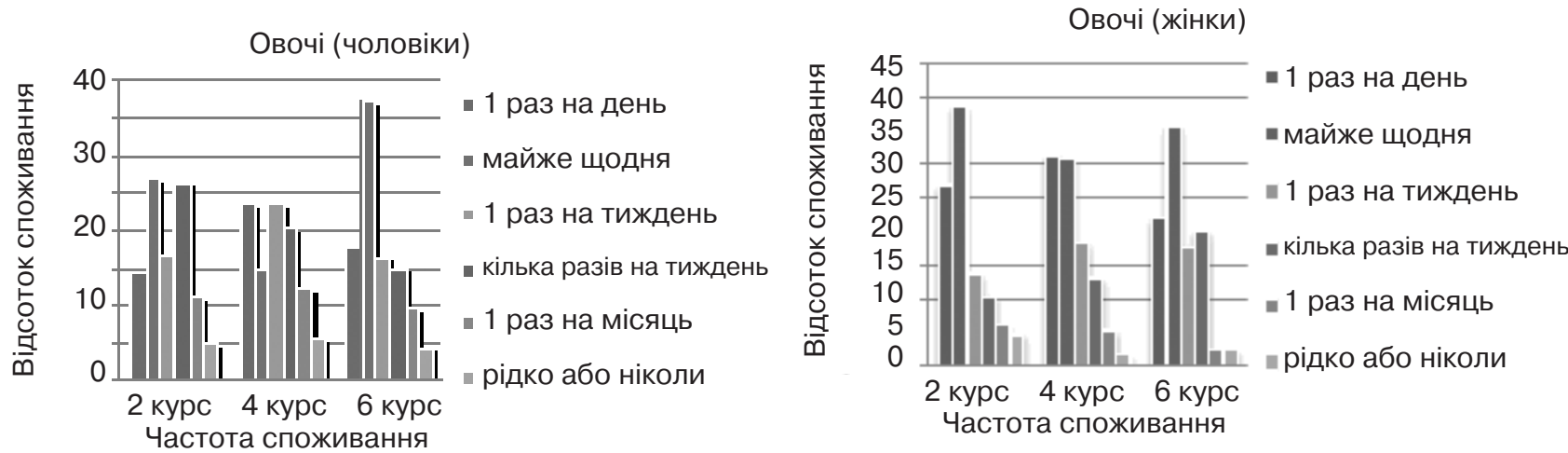

Рисунок 2

\section{Частота споживання картоплі студентами-медиками}

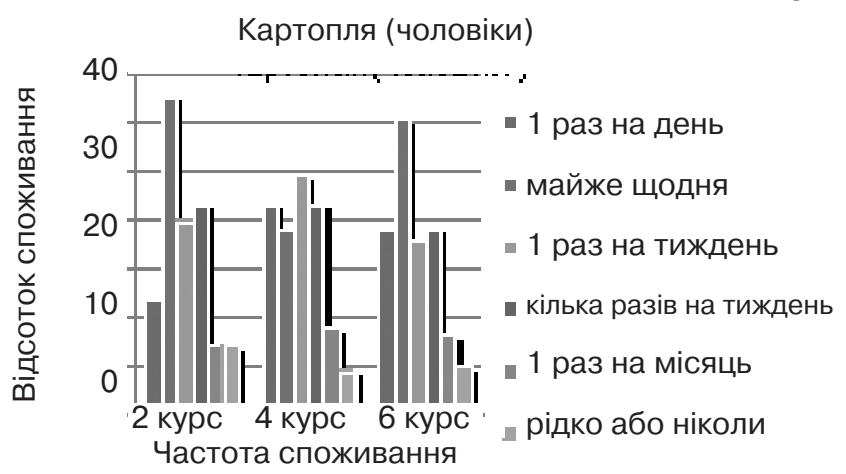

Картопля (жінки)

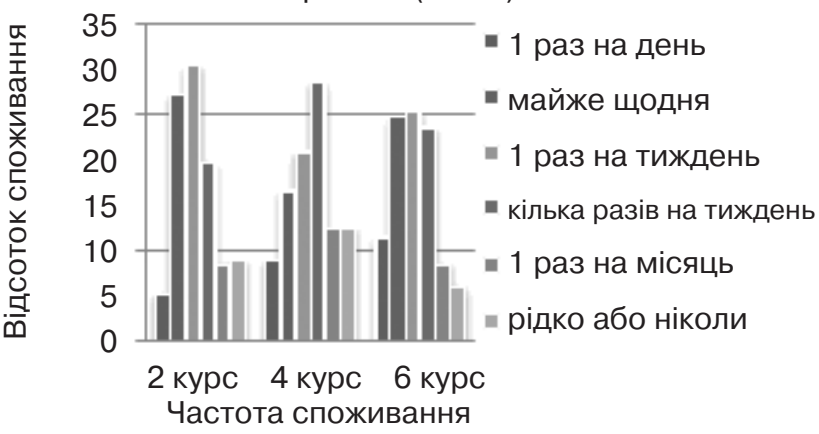

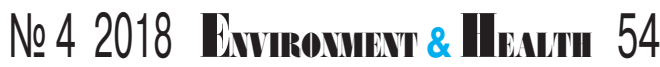


21,8\% та 35,8\% жіночої; 1 раз на тиждень або декілька разів на тиждень - $16,4 \%$ та $15,0 \%$ чоловічої статі і 17,6\% та 20,0\% жіночої; 1 чи декілька разів на місяць або рідко чи ніколи - 9,6\% та $4,2 \%$ чоловічої статі і $2,4 \%$ та 2,4\% жіночої (рис. 1).

При оцінюванні частоти споживання картоплі виявлено, що до свого раціону її щоденно або майже щодня включають 11,9\% та 32,5\% респондентів 2 курсу чоловічої статі і 5,2\% та 27,2\% жіночої (рис. 2).

Встановлено, що картоплю споживають 1 раз на тиждень або декілька разів на тиждень $19,9 \%$ та 21,4\% чоловічої статі і $30,5 \%$ та 19,7\% жіночої; 1 чи декілька разів на місяць або рідко чи ніколи 7,15\% та 7,15\% чоловічої статі і 8,5\% та $8,9 \%$ жіночої; щоденно або майже щодня споживають $21,35 \%$ та 19,1\% відповідно респондентів 4 курсу чоловічої статі і 8,9\% та 16,65\% жіночої; 1 раз на тиждень або декілька разів на тиждень $24,7 \%$ та 21,35\% чоловічої статі і $20,85 \%$ та 28,6\% жіночої статі; 1 чи декілька разів на місяць або рідко чи ніколи 9,0\% та $4,5 \%$ чоловічої статі і $12,5 \%$ та $12,5 \%$ жіночої; щоденно або майже щодня споживають $19,2 \%$ та 30,15\% відповідно респондентів 6 курсу чоловічої статі і 11,5\% та 24,85\% жіночої; 1 раз на тиждень або декілька разів на тиждень $17,8 \%$ та $19,2 \%$ чоловічої статі і

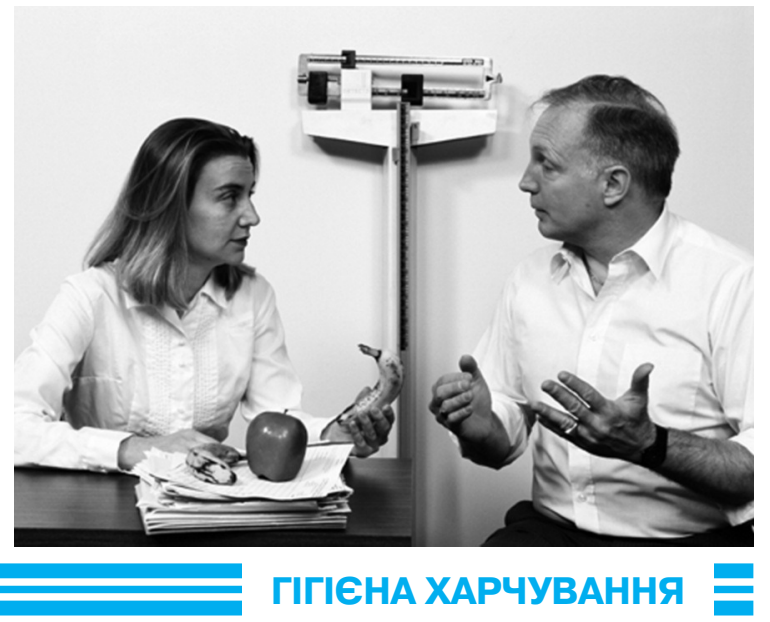

$25,45 \%$ та 23,65\% жіночої; 1 чи декілька разів на місяць або рідко чи ніколи $8,2 \%$ та $5,0 \%$ чоловічої статі і 8,5\% та $6,06 \%$ жіночої (рис. 2).

При оцінюванні частоти споживання фруктів і ягід виявлено, що до свого раціону їх щоденно або майже щодня включають 14,3\% та 23\% відповідно респондентів 2 курсу чоловічої статі і $36,6 \%$ та 31,0\% жіночої (рис. 3).

Виявлено, що до свого раціону фрукти і ягоди включають 1 раз на тиждень або декілька разів на тиждень $17,4 \%$ та 25,4\% чоловічої статі і 7,5\% та $12,7 \%$ жіночої; 1 чи декілька разів на місяць або рідко чи ніколи $16,7 \%$ та $3,2 \%$ чоловічої статі і 9,85\% та 2,35\% жіночої; щоденно або майже щодня включають 22,47\% та $15,73 \%$ відповідно респондентів 4 курсу чоловічої статі і 29,15\% та 31,25\% жіночої; 1 раз на тиждень або декілька разів на тиж- день $19,1 \%$ та 23,6\% чоловічої статі і 22,4\% та 10,4\% жіночої; 1 чи декілька разів на місяць або рідко чи ніколи $11,2 \%$ та $7,9 \%$ чоловічої статі і 3,6\% та 3,2\% жіночої; щоденно або майже щодня включають $16,4 \%$ та $31,5 \%$ респондентів 6 курсу чоловічої статі і 20,7\% та 29,0\% жіночої; 1 раз на тиждень або декілька разів на тиждень 23,3\% та 17,6\% жіночої; 1 чи декілька разів на місяць або рідко чи ніколи $9,6 \%$ та 5,5\% чоловічої статі і 10,9\% та 3,0\% жіночої (рис. 3).

При оцінюванні частоти споживання хліба і хлібобулочних виробів виявлено, що їх щоденно або майже щодня споживають 38,9\% та 33,4\% відповідно респондентів 2 курсу чоловічої статі і 30,5\% та 17,0\% жіночої (рис. 4).

Виявлено, що хліб і хлібобулочні вироби споживають 1 раз на тиждень або декілька разів на та $13,7 \%$ чоловічої статі і $18,8 \%$

\section{Частота споживання фруктів і ягід студентами-медиками}

Рисунок 3
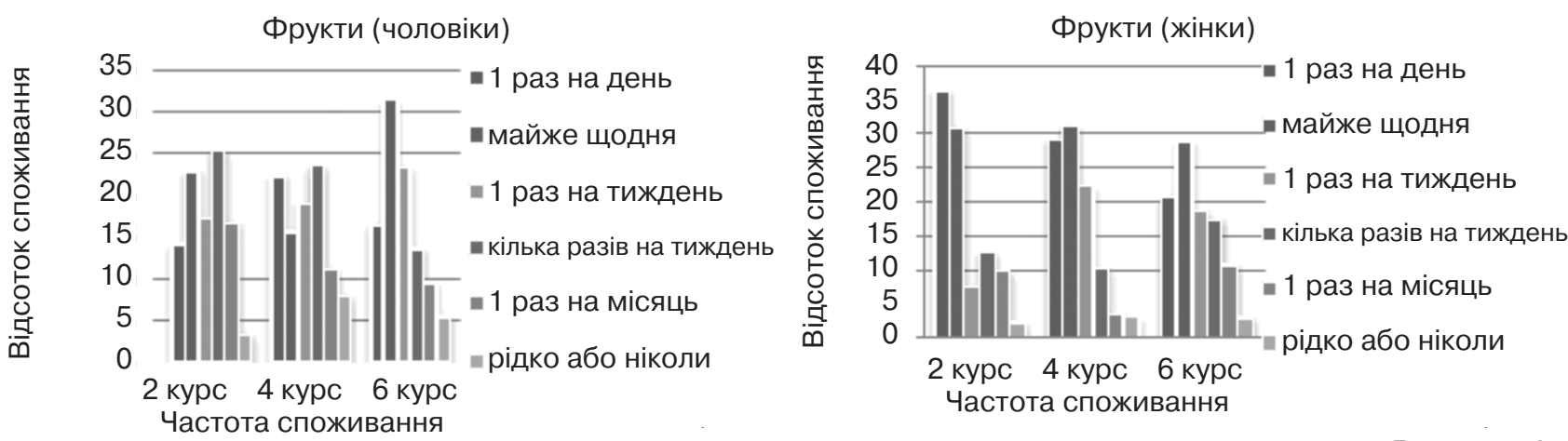

Частота споживання хліба і хлібобулочних виробів студентами-медиками

Рисунок 4

Хліб (чоловіки)

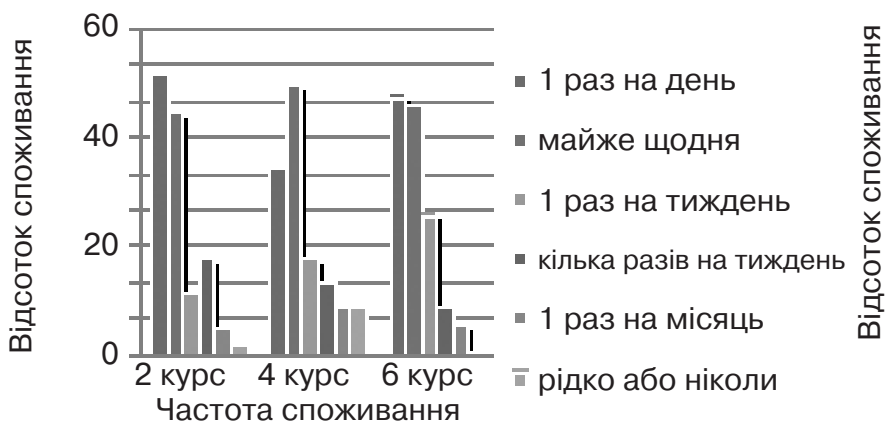

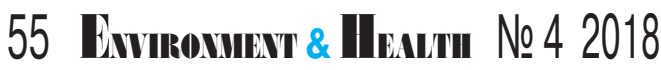

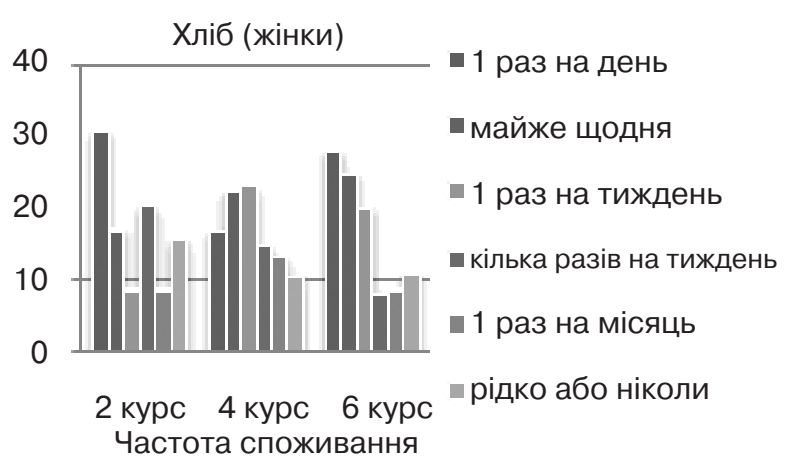


тиждень 8,7\% та 13,5\% чоловічої статі і 8,45\% та 20,1\% жіночої; 1 чи декілька разів на місяць або рідко чи ніколи $4,0 \%$ та $1,5 \%$ чоловічої статі і $8,45 \%$ та $15,5 \%$ жіночої; щоденно або майже щодня споживають $25,9 \%$ та $37,0 \%$ відповідно респондентів 4 курсу чоловічої статі і 16,7\% та 22,4\% жіночої; 1 раз на тиждень або декілька разів на тиждень $13,5 \%$ та $10,1 \%$ чоловічої статі і $22,9 \%$ та 14,6\% жіночої; 1 чи декілька разів на місяць або рідко чи ніколи $6,75 \%$ та $6,75 \%$ чоловічої статі і 13,0\% та 10,4\% жіночої; щоденно або майже щодня споживають $35,6 \%$ та $34,24 \%$ відповідно респондентів 6 курсу чоловічої статі і 27,9\% та 24,8\% жіночої; 1 раз на тиждень або декілька разів на тиждень $19,2 \%$ та $6,85 \%$ чоловічої статі і $20,0 \%$ та $7,9 \%$ жіночої; 1 чи декілька разів на місяць або рідко чи ніколи 4,2\% та 0,0\% чоловічої статі і 8,5\% та $10,9 \%$ жіночої (рис. 4).

При оцінюванні частоти споживання круп і макаронних виробів виявлено, що їх щоденно або майже щодня споживають 19,0\% та 29,3\% відповідно респондентів 2 курсу чоловічої статі і 18,8\% та 24,8\% жіночої (рис. 5).

Встановлено, що до свого раціону крупи і макаронні вироби включають 1 раз на тиждень або декілька разів на тиждень 14,3\% та 25,4\% чоловічої статі і 23,95\% та 21,15\% жіночої; 1 чи декілька разів на місяць або рідко чи ніко- ли 8,0\% та 4,0\% чоловічої статі і $6,1 \%$ та 5,2\% жіночої; щоденно або майже щодня включають 29,2\% та 21,35\% відповідно респондентів 4 курсу чоловічої статі і 14,6\% та 21,35\% жіночої; 1 раз на тиждень або декілька разів на тиждень $16,9 \%$ та $12,35 \%$ чоловічої статі і 22,4\% та 20,8\% жіночої; 1 чи декілька разів на місяць або рідко чи ніколи $10,1 \%$ та $10,1 \%$ чоловічої статі і $14,6 \%$ та $6,25 \%$ жіночої; щоденно або майже щодня включають 24,65\% та $30,15 \%$ відповідно респондентів 6 курсу чоловічої статі і 17,0\% та 32,1\% жіночої; 1 раз на тиждень або декілька разів на тиждень $13,7 \%$ та $17,8 \%$ чоловічої статі $22,4 \%$ та 17,6\% жіночої; 1 чи декілька разів на місяць або рідко чи ніколи 6,85\% та 6,85\% чоловічої статі і $6,05 \%$ та $4,85 \%$ жіночої (рис. 5).

При оцінюванні частоти споживання солодощів (цукру, варення, меду) виявлено, що їх щоденно або майже щодня споживають $19,0 \%$ та $32,6 \%$ відповідно респондентів 2 курсу чоловічої статі і $31,0 \%$ та 27,7\% жіночої (рис. 6).

Виявлено, що до свого раціону солодощі включають 1 раз на тиждень або декілька разів на тиждень $20,6 \%$ та $15,0 \%$ чоловічої статі і $16,0 \%$ та $6,1 \%$ жіночої; 1 чи декілька разів на місяць або рідко чи ніколи 5,6\% та 7,2\% чоловічої статі і 8,0\% та $11,2 \%$ жіночої; щоденно або майже щодня включають 23,6\% та 23,6\% відповідно респондентів 4 курсу чоловічої статі і 10,4\% та 12,0\% жіночої; 1 раз на тиждень або декілька разів на тиждень $18,0 \%$ та $14,6 \%$ чоловічої статі і $23,5 \%$ та 25,5\% жіночої; 1 чи декілька разів на місяць або рідко чи ніколи $12,3 \%$ та 7,9\% чоловічої статі і $18,2 \%$ та $10,4 \%$ жіночої; щоденно або майже щодня $13,7 \%$ та 22,0\% відповідно респондентів 6 курсу чоловічої статі і $21,2 \%$ та 23,0\% жіночої; 1 раз на тиждень або декілька разів на тиждень $19,2 \%$ та 24,65\% чоловічої статі і 23,0\% та 12,7\% жіночої; 1 чи декілька разів на місяць або рідко чи ніколи $15,0 \%$ та $5,0 \%$ чоловічої статі і 10,4\% та 9,7\% жіночої (рис. 6)

\section{Висновки}

Встановлено, що 70\% студентських раціонів за наповненням їх продуктами рослинного походження не відповідають національним рекомендаціям за частотою їх споживання.

Лише третина респондентів жіночої статі та 15-25\% респондентів чоловічої статі використовують у своєму раціоні овочі щоденно. Від 17\% респондентів жіночої статі (2 курс) до 25\% (6 курс), а також третина респондентів чоловічої статі, незалежно від курсу, споживають щоденно картоплю. До $40 \%$ респондентів чоловічої статі та до 31\% жіночої щодня споживають фрукти. Хліб і хлібобулочні виро-

Частота споживання круп, макаронних виробів студентами-медиками

Рисунок 5
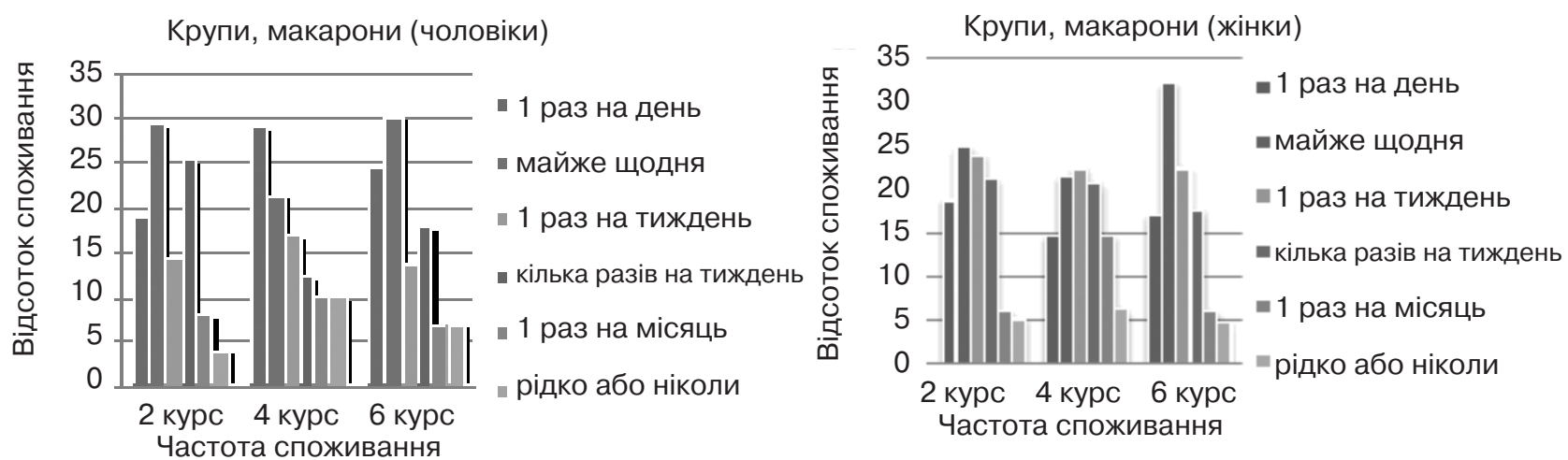

Частота споживання солодощів (цукру, варення, меду) студентами-медиками

Рисунок 6

Солодощі (чоловіки)

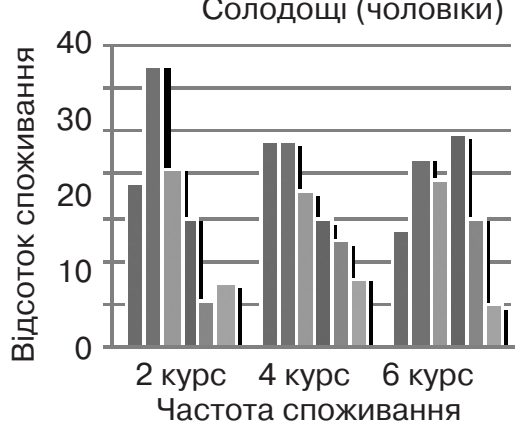

I= 1 раз на день

I= майже щодня

I" 1 раз на тиждень

Iп кілька разів на тижден

I= 1 раз на місяць

I= рідко або ніколи

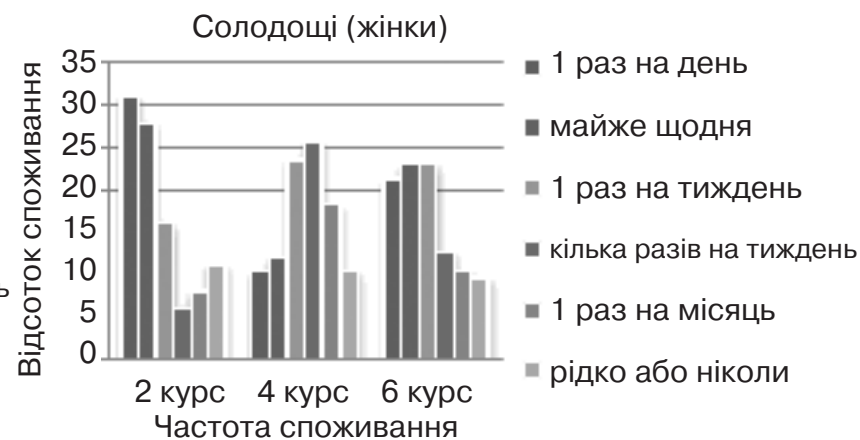

Частота споживання 
PREVENTION OF HYPOVITAMINOSIS

AND HYPOMICROELEMENTOSIS

IN THE UNIVERSITY STUDENTS

Yeltsova L.B., Omelchuk S.T., Aleksiichuk V.D., Petrosian A.A.

O. Bohomolets National Medical University, Kyiv, Ukraine

Objectives: We estimated the frequency of the consumption of the food of vegetable origin in the food intake of the university students for the prevention of hypovitaminosis and hypomicroelementosis states.

Materials and methods: The authors surveyed the students of the 2-nd, 4-th and 6-th study years at 0 . Bohomolets National Medical University, using the questionnaire, and analyzed the obtained data on the medical students' food intakes. The study included the data of 858 respondents ( 570 females and 288 males) aged $18-25$ years old.

Results: The study represents the results of the estimation of the consumption of food of vegetable origin in the food intake of medical students. The consumption frequency of mentioned products was estimated according to the following grading: consumption once a day or more often, almost every day, once a week, some times a week, once or several times a month, rarely or never. The consumption frequency of such traditional for Ukrainians vegetables, as beet, carrot, cabbage and greenery was estimated. Taking into account national cuisine traditions, consumption of potatoes was assessed separately. Study of the consumption of fruit and berries, bread and bakery products, sweet products (sugar, jam, and honey), cereals, and pasta was performed as well.

Conclusions: Only one third of the female respondents and $15-25 \%$ of the male ones consume vegetables every day. From 17\% (the 2-nd year of study) to $25 \%$ of the female respondents (the 6 -th year of study) and one third of the male respondents, irrespective of the year of study, consume potatoes every day. Up to $40 \%$ of the male and $31 \%$ of the female respondents consume fruit daily. Bread and bakery products are consumed by up to $40 \%$ of the male and $30 \%$ of the female respondents daily. Cereals and pasta are consumed by almost $30 \%$ of the male and $15-19 \%$ of the female respondents every day or almost every day. One third of the male respondents and only $10-12 \%$ of the female ones consume sweet products (sugar, jam, honey) daily. In general, $70 \%$ of the students' food intakes don't comply with the National Guidelines on Nutrition.

Keywords: consumption frequency, questionnaire, food of vegetable origin, food intake, alimentary diseases, University students. би споживають щодня до 40\% респондентів чоловічої статі та до $30 \%$ жіночої. Щоденно споживають крупи і макаронні вироби до $30 \%$ респондентів чоловічої статі та 15-19\% жіночої. Третина респондентів чоловічої статі використовує у своєму раціоні щодня солодощі (цукор, варення, мед) та лише 10-12\% респондентів жіночої.

Ситуація, що склалася, може призвести до розвитку нутрієнтних дефіцитів (гіповітамінозів, гіпомікроелементозів) та аліментарнозалежних захворювань. 3 метою профілактики дефіцитів нутрієнтів необхідно проводити науково обґрунтовану індивідуальну корекцію харчових раціонів студентської молоді відповідно до національних рекомендацій зі здорового харчування.

\section{ЛІТЕРАТУРА}

1. Єльцова Л.Б., Омельчук С.Т. Обґрунтування шляхів удосконалення анкетно-опитувального методу оцінки фактичного харчування населення. Медичні перспективи. 2017. № 3. С. 104-112.

2. Про затвердження Норм фізіологічних потреб населення України в основних харчових речовинах і енергії : Наказ МО3 України № 1073 від 03.09.2017. Київ, 2017. URL : http://zakon2. rada.gov.ua/laws/show/z1206-17

3. Півень Н. Рекомендації щодо здорового харчування дорослих. Практикуючий лікар. 2018. № 1. С. 39-46.

4. Григоренко А. Методичні рекомендації для лікарів загаль- ної практики - сімейної медицини з приводу консультування пацієнтів щодо основних засад здорового харчування. Наказ МО3 № 16 від 14.01.2013. К., 2013. $30 \mathrm{c}$.

5. Матасар І.Т., Ципріян В.І., Горчакова Л.А. та ін. Первинна та вторинна профілактика аліментарнозалежних захворювань : метод. рек. Київ, 2007. 80 с.

6. Аністратенко Т.І., Білко Т.М., Благодарова О.В. та ін. Гігієна харчування з основами нутриціології. Київ : Медицина, 2007. С. 327-372.

7. Швец О.В. Значение достаточной и сбалансированной диеты в профилактике наиболее опасных болезней современности. Питание и здоровье. 2010.

№ 1. С. 9-14.

8. Omelchuk S.T., Kuzminska O.V., Gulay T.O., Lymar L.V. General Nutrition : Stadi Guide for the 4-th Accreditation Level Medical School Students. Kyiv , 2016. 146 p.

REFERENCES

1. Yeltsova L.B. and Omelchuk S.T. Medychni perspektyvy. 2017; 3 : 104-112 (in Ukrainian). 2. Pro zatverdzhennia Norm fiziolohichnykh potreb naselennia Ukrainy v osnovnykh rechovynakh I enerhii : nakaz MOZ Ukrainy № 1073 vid 03.09.2017 [On the Approval of the Norms of the Physiological Needs of the Population of Ukraine in the Main Nutrients and Energy : Order of the Ministry of Health № 1073, 03.09.2017]. URL :

http://zakon2.rada.gov.ua/laws/s how/z1206-17 (in Ukrainian).

3. Piven N. Praktykuiuchyi likar. 2018; 1: 39-46 (in Ukrainian). 4. Hryhorenko A. Metodychni rekomendatsii dlia likariv zahalnoi praktyky - simeinoi medytsyny z pryvodu konsultuvannia patsiientiv shchodo osnovnykh zasad zdorovoho kharchuvannia : metodychni rekomendatsii [Methodical

Recommendations for General Practitioners of Family Medicine on Counseling Patients Regarding the Basic Principles of Healthy Eating (the Order of the Ministry of Health of Ukraine №16 from 14.01.2013]. Kyiv; 2013 : 30 p. (in Ukrainian).

5. Matasar I.T., Tsypryian V.I., Horchakova L.A. et al. Pervynna ta vtorynna profilaktyka alimentarnozalezhnykh zakhvoriuvan : metodychni rekomendatsii [Primary and Secondary Prevention of AlimentaryDependent Diseases : Methodical Recommendations]. Kyiv ; 2007 : 80 p. (in Ukrainian)

6. Anistratenko T.I., Bilko T.M., Blahodarova O.V. et al. Hihiiena kharchuvannia z osnovamy nutritsiolohii [Hygiene of Nutrition with the Principles of Nutritionology]. Kyiv: Medytsyna; 2007 : 327-372 (in Ukrainian).

7. Shvets O.V. Pitanie i zdorovie. 2010 ; 1: 9-14 (in Russian).

8. Omelchuk S.T., Kuzmin-

ska O.V., Gulay T.O. and Lymar L.V. General Nutrition : Stady Guide for the 4-th Accreditation Level Medical School Students. Kyiv; $2016: 146 \mathrm{p}$

Надійшла до редакції 15.07.2018 